\title{
$\mathrm{ICP} / \mathrm{MS}$ 를 이용한 축산물의 유해중금속 분석방법 및 숙련도 검증
}

\author{
장정희 · 김동규 · 권현정 · 임채미·손성완 · 김미경* \\ 농림수산검역검사본부
}

(접수: 2011년 10월 13일, 수정: 2012년 1월 3일, 게재승인: 2012년 1월 4일)

\section{Method and proficiency test for analysis of toxic metals in livestock products by ICP/MS}

\author{
Jung-Hee Jang, Dong-Gyu Kim, Hyun-Jeong Kwon, Chae-mi Lim, Seong-Wan Son, MeeKyung Kim* \\ Animal, Plant and Fisheries Quarantine and Inspection Agency, Anyang 430-757, Korea \\ (Received: October 13, 2011; Revised: January 3, 2012; Accepted: January 4, 2012)
}

\begin{abstract}
The analytical method of trace toxic metals in livestock products was confirmed and validated through certified reference material (CRM) and the international proficiency tests. There are some difficulties to determine low levels of toxic metals in livestock products because of interferences due to the matrix. The recoveries of CRM (NIST 1577c) ranged from 73.9 to $119 \%$ for lead and from 86.4 to $111 \%$ for cadmium in bovine liver. The international proficiency tests were carried out with the milk powder and cocoa powder samples including metals provided by Food Analysis Performance Assessment Scheme $\left(\right.$ FAPAS $^{\circledR}$, UK). The test samples were prepared by microwave digestion using solution of $\mathrm{HNO}_{3}: \mathrm{H}_{2} \mathrm{O}_{2}: \mathrm{H}_{2} \mathrm{O}(\mathrm{v} / \mathrm{v} / \mathrm{v}=5: 2: 4)$ and analyzed by ICP/MS. The analytical result of cadmium in milk powder was $121 \mu \mathrm{g} / \mathrm{kg}$ with -0.3 of the z-score compared to the assigned value of $131 \mu \mathrm{g} / \mathrm{kg}$ by FAPAS ${ }^{\circledR}$. The analytical results of lead and cadmium in cocoa powder were $29.2 \mu \mathrm{g} / \mathrm{kg}$ and $97.6 \mu \mathrm{g} / \mathrm{kg}$, respectively, which satisfied the assigned values of $34.2 \mu \mathrm{g} / \mathrm{kg}$ for lead and $126 \mu \mathrm{g} / \mathrm{kg}$ for cadmium by FAPAS ${ }^{\circledR}$. It is verified that the analytical method is accurate and reliable to determine trace lead and cadmium in livestock products by microwave digestion and ICP/MS.
\end{abstract}

Keywords : cadmium, ICP/MS, lead, livestock product, microwave digestion

서 론

유해중금속은 난분해성 물질이며 생체 축적성이 강하 므로 축산식품에 잔류 할 경우 인체로 이행될 수 있으 므로 체내에 다량 축적되는 경우에는 중독 증상을 유발 하는 것으로 알려져 있다. 특히 납에 의한 중독은 악성 빈혈을 일으키고, 카드뭄에 의한 중독은 단백뇨나 이타 이이타이병을 유발한다. 또한 유해 중금속은 생식기능 을 비롯한 각종 생체대사에 영향을 미칠 수 있는 내분 비계장애물질로 알려져 있다. 최근 식품 안전에 대한 관 심과 우려가 높아짐에 따라 생체에 축적되는 경우 여러 종류의 중독증상을 유발시킬 수 있는 유해 중금속의 조 사연구가 매우 필요한 실정이다.
축산물의 중금속 분석은 원자흡광 광도계(atomic absorption spectrometer, AAS)에 비하여 기기의 정량한 계가 낮은 유도결합플라스마/원자방출분광기(inductively coupled plasma/atomic emission spectrometer, ICP/AES)나 유도결합플라스마 질량분석기(inductively coupled plasma/ mass spectrometer, ICP/MS)를 주로 사용한다 [3]. 본 연 구에서는 part per billion 내지 part per trillion 수준의 극 미량 유해중금속을 분석하기 위하여 4중극자(quadrupole) ICP/MS를 사용하였다. ICP/MS는 시험 용액 중의 분석 원소를 유도결합플라스마에 의해 이온화하여, 이온화된 원소의 질량/전하 $(\mathrm{m} / \mathrm{z})$ 비율에 따라 분리된 이온 스펙트 럼과 그의 세기에 의해 각각 정성 또는 정량 분석하는 방법이다. 극미량의 중금속을 분석하기 위한 시료의 전

\footnotetext{
*Corresponding author

Tel: +82-31-467-1982, Fax: +82-31-467-1833

E-mail: mkim@korea.kr
} 
처리 방법은 극초단파를 에너지원으로 이용하여 비교적 낮은 온도에서도 시료를 신속하고 안전하게 분해할 수 있는 마이크로웨이브법을 사용하였다 [6].

국내에서 2011년 1월 1일부터 축산물 중 중금속 허용 기준(식품의약품안전청 공고 제2009-227호)이 시행됨에 따라 납은 $0.1 \mathrm{mg} / \mathrm{kg}$, 카드뮴은 $0.05 \mathrm{mg} / \mathrm{kg}$ 이하의 검출 이 가능한 분석방법이 사용되어야 한다. 국외에서는 유 럽연합(EU)과 국제식품규격위원회(CODEX)에서 중금속 잔류허용기준이 설정되어 있어, 여러 국가에서 축산물 의 중금속 분석방법을 확립하고 잔류조사를 수행하여 왔다 [1, 2, 7-9]. 그러므로 우리나라에서도 축산물의 미 량 유해중금속에 대한 정확하고 정밀한 시험법의 확립 과 잔류조사가 시급한 실정이다. '축산물의 가공기준 및 성분규격'(농림수산검역검사본부 고시 제2011-105호)에 초고압초음파법과 $\mathrm{ICP} / \mathrm{MS}$ 법을 이용한 유해성금속의 시 험법이 있으나 납 분석 결과의 정확도가 떨어지는 경향 이 있다. 오차의 원인을 파악하고 이를 배제시켜야 정확 한 분석결과를 얻을 수 있으므로 본 연구에서는 오차의 원인 중에서 시험과정의 오염에 초점을 두고, 시료채취, 실험과정, 실험실 환경 및 실험기구 등의 다양한 오염원 을 점검하고 확인된 오염원을 제거하고자 하였다. 또한 시험법을 확립한 후 이를 검증하고자 국제비교숙련도시 험에 참여하고 검증된 시험법을 상세하게 기술함으로써 축산물의 유해중금속 분석과 유해물질로부터 안전한 축 산물 공급에 기여하고자 하였다 [5].

\section{재료 및 방법}

\section{시료의 개요}

유해중금속 분석방법을 검증하기 위하여 분석 시료는 회수율시험을 위한 인증표준물질(certified reference material, CRM, NIST 1577c, bovine liver powder)과 영 국 식품 환경 연구기관(The Food and Environment Research Agency) 소속의 식품분석능력 평가기구(Food Analysis Performance Assessment Scheme, FAPAS ${ }^{\circledR}$ 로부 터 구매한, 납과 카드뮴이 포함된 우유분말과 코코아분 말을 사용하였다.

\section{시약 및 기구}

중금속 표준물질은 납, 카드뮴, 인듐이 혼합되어 있는 표준품(AccuStandard, USA)을 사용하였다. 그 이외의 시 약은 ultra 및 supra grade 질산(Merck, Germany), supra grade 과산화수소(Merck, Germany)를 사용하였다. 표준 액 제조 및 시료분해에 소비되는 질산은 ultra grade 질 산, 세척에는 supra grade 질산으로 용도에 따라 분류해 서 사용하였다. 실험 전반에 사용되는 초 순수 정제수는 중금속 전용 초 순수 제조장치(Milli-Q element; Millipore, $\mathrm{USA}$ )를 이용하였다. 실험에 사용한 중금속 분해용기는 마이크로웨이브 분해기(Q-Lab 6000; Questron corporation, $\mathrm{USA}$ )에서 세척하고 약 $10 \%$ 질산과 초 순수 정제수에 각각 24 시간 이상 담근 후에 용기의 오염도를 측정하 였다. 오염도 측정은 분해용기에 초 순수 정제수 $15 \mathrm{~mL}$ 를 넣고 가열기(heating block)에서 2시간 동안 끓인 후 용기내의 정제수 중 납과 카드뮴의 농도를 ICP/MS로 분 석하였다. 오염도가 거의 없다고 판단된 분해용기만을 실험에 사용하였으며, 오염도가 확인된 용기는 위의 세 척과정을 재 반복하여 확인하거나 실험에 사용하지 않 았다.

\section{시료 전처리}

분해용기에 시료 약 $0.3 \mathrm{~g}$ 을 넣고 ultra grade 질산 5 $\mathrm{mL}$, supra grade 과산화수소 $2 \mathrm{~mL}$ 와 내부표준물질로 100 $\mathrm{ng} / \mathrm{mL}$ 농도의 인듐 $100 \mu \mathrm{L}$ 를 넣고 후드에서 약 2 시간 동안 정치하여 예비 분해가 이루어지도록 하였다. 그 다 음, 초 순수 정제수 $4 \mathrm{~mL}$ 를 추가하여 마이크로웨이브 분해기에서 분해하였다. 마이크로웨이브 분해기의 최적 분해 온도 프로그램은 Table 1과 같다. 분해된 시료액을 $4^{\circ} \mathrm{C}$ 에서 12 시간 동안 정치한 후 polypropylene sample tube로 옮기고 초 순수 정제수를 가하여 희석한 후 검액 으로 사용하였다. 정확한 극미량 분석을 위하여 시료 전 처리와 동일한 과정을 거친 바탕시험용액(system blank) 을 분석한 후 시료분석 결과를 보정하였다.

\section{기기 분석}

4중극자 유도결합플라스마 질량분석기(ICP/MS, Elan DRC II; Perkin Elmer, USA)를 이용하여 시료 중 납과

Table 1. Temperature program of microwave digestion

\begin{tabular}{ccccc}
\hline \hline Step & Temperature $\left({ }^{\circ} \mathrm{C}\right)$ & Power $(\mathrm{W})$ & Ramp $(\mathrm{min})$ & Dwell $(\mathrm{min})$ \\
\hline 1 & 100 & 750 & 5 & 5 \\
2 & 130 & 750 & 10 & 5 \\
3 & 160 & 750 & 10 & 10 \\
4 & 180 & 750 & 10 & 20 \\
\hline
\end{tabular}


Table 2. Analytical results for certified reference material"

\begin{tabular}{|c|c|c|c|c|c|}
\hline \multirow[b]{2}{*}{ Element } & \multirow{2}{*}{$\begin{array}{l}\text { Certified value } \\
\qquad(\mathrm{mg} / \mathrm{kg})\end{array}$} & \multicolumn{2}{|c|}{ Determined value (mg/kg) } & \multicolumn{2}{|c|}{$\%$ Recovery $(\mathrm{n}=18)$} \\
\hline & & $\begin{array}{c}\text { in Ultra grade } \\
\mathrm{HNO}_{3}\end{array}$ & $\begin{array}{c}\text { in Supra grade } \\
\mathrm{HNO}_{3}\end{array}$ & $\begin{array}{c}\text { in Ultra grade } \\
\mathrm{HNO}_{3}\end{array}$ & $\begin{array}{c}\text { in Supra grade } \\
\mathrm{HNO}_{3}\end{array}$ \\
\hline Lead & $0.063 \pm 1.0$ & $0.065 \pm 8.7$ & $0.065 \pm 15.8$ & $103 \pm 13.8$ & $103 \pm 25.1$ \\
\hline Cadmium & $0.097 \pm 1.4$ & $0.098 \pm 8.5$ & $0.097 \pm 12.0$ & $101 \pm 8.8$ & $100 \pm 12.4$ \\
\hline Indium $^{\dagger}$ & 0.10 & $0.098 \pm 8.1$ & $0.093 \pm 9.1$ & $98 \pm 8.1$ & $93 \pm 9.2$ \\
\hline
\end{tabular}

*NIST $1577 \mathrm{c}$ (Metals in bovine liver). "Internal standard.

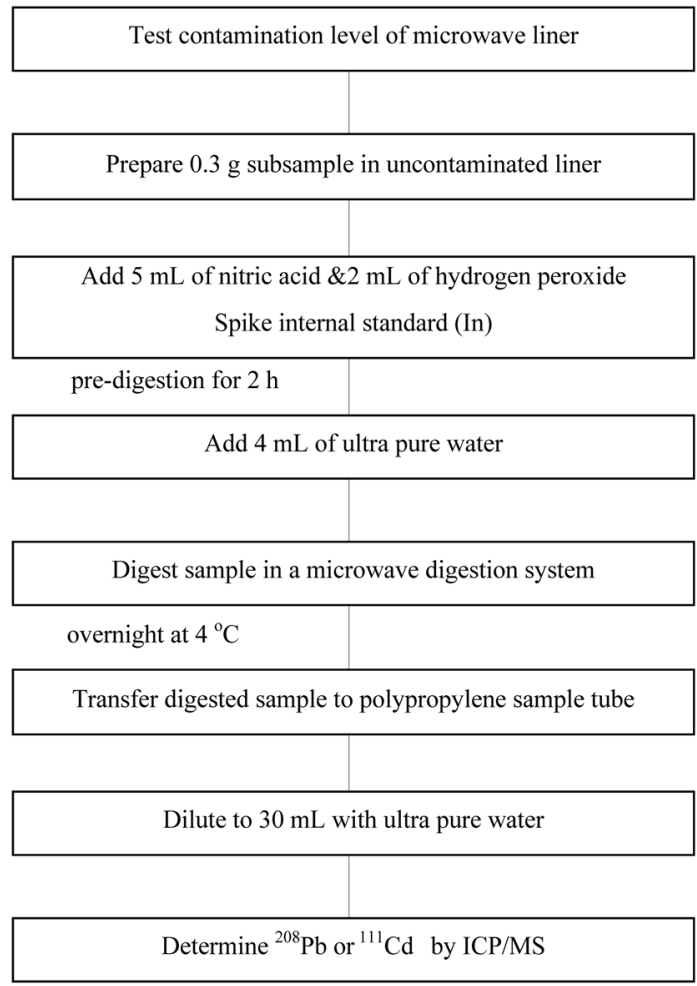

Fig. 1. Flow chart for analysis of cadmium and lead.

카드뮴의 정성, 정량 분석 및 표준물질을 확인하였다. 분 광학적 간섭을 배제하기 위하여 ${ }^{208} \mathrm{~Pb},{ }^{111} \mathrm{Cd},{ }^{115} \mathrm{In}$ 을 분 석에 사용하였다.

\section{결 과}

축산물의 유해중금속 분석방법을 Fig. 1의 과정에 따 라 확립하였고, 이를 검증하고자 회수율 시험과 세계 각 국의 분석 실험실이 참여한 국제비교숙련도시험을 수행 하였다. 분석물질로는 2011년 1월부터 잔류허용기준이 적용되는 납과 카드뭄을 선정하였다. 소의 간장 분말 (bovine liver powder)에 $0.063 \mathrm{mg} / \mathrm{kg}$ 의 납과 $0.097 \mathrm{mg} / \mathrm{kg}$
의 카드뮴이 함유된 $\mathrm{CRM}$ 을 분석하여 회수율을 시험하 였다.

$\mathrm{CRM}$ 을 이용한 회수율 측정으로 분석의 정확도와 정 밀도를 확인할 수 있으므로 다음과 같이 총 18 회의 반 복시험을 통하여 회수율 및 표준편차를 구하였으며 그 결과를 Table 2에 나타내었다. 우선 전처리 과정에서 사 용하는 질산의 등급을 결정하기 위하여 ultra 또는 supra grade의 질산을 각각 사용하여 시료를 분해시키고 결과 를 비교하였다. Ultra 또는 supra grade의 질산은 중금속 함유량에 따라 그 등급이 결정되며 ultra grade가 중금속 함유량이 적지만 고가인 단점을 가지고 있다. Ultra grade 의 질산을 사용하여 시료를 분해하였을 경우에 납, 카드 뮴, 인듐의 회수율 범위가 각각 79.8 128\%, 86.4 116\%, $84.2 \sim 111 \%$ 이었고, supra grade를 사용한 경우 납, 카드 뮴, 인듐의 회수율 범위가 각각 $65.7 \sim 143 \%, 88.8 \sim 136 \%$, $82.9 \sim 119 \%$ 이었다. Ultra grade를 사용한 경우의 회수율 이 supra grade를 사용한 경우보다 양호하였으며, 표준 편차도 같은 결과를 보였다. 질산 등급과 원소별 관계를 살펴보면, 카드뮴과 인듐의 경우는 표준편차의 차이가 거의 없는데 비하여 납의 경우는 ultra와 supra grade 사 용 시 표준편차가 2 배 정도 차이가 있으므로 납 분석에 서는 시약의 순도가 결과 값에 미치는 영향이 큰 것으 로 확인되었다.

분석방법의 반복성 시험 후 $\mathrm{CRM}$ 을 이용하여 약 한 달 동안 10 회의 실험으로 분석방법의 재현성을 시험하 였다. 그 결과, 납의 평균 회수율은 93.7\%(73.9 119\%), 카드뮴의 평균 회수율은 $95.9 \%(86.4 \sim 111 \%)$ 로 분석방법 의 재현성이 매우 양호한 것으로 나타났다. 회수율 시험 결과로 본 시험법 및 시험자의 숙련도에 문제가 없는 것 으로 판단되어, 국제비교숙련도시험에 참여하였다. 우유 분말 및 코코아분말 각각에 미지 농도의 납 또는 카드 뮴이 함유된 국제비교숙련도시험 시료를 동일한 과정을 거쳐 분석하여 함유된 중금속의 농도를 정성 및 정량 분 석하였다. 비교숙련도시험은 매질에 함유된 중금속 농 도를 분석하는 시험으로, 결과의 신뢰성 판단은 분석된 중금속 농도와 본래 시료에 포함된 중금속 농도의 차이 
Table 3. Analytical result and z-score for milk powder in FAPAS ${ }^{\circledR}$ proficiency test

\begin{tabular}{ccc}
\hline \hline \multirow{2}{*}{ Laboratory number } & \multicolumn{2}{c}{ Analyte } \\
\cline { 2 - 3 } & \multicolumn{3}{c}{ Cadmium $($ Assigned value $=131 \mu \mathrm{g} / \mathrm{kg})$} \\
\cline { 2 - 3 } & Analytical result $(\mu \mathrm{g} / \mathrm{kg})$ & Z-score \\
\hline $34^{*}$ & 121 & -0.3 \\
\hline
\end{tabular}

*Animal, Plant and Fisheries Quarantine and Inspection Agency.

Table 4. Analytical results and z-score for cocoa powder in FAPAS ${ }^{\circledR}$ proficiency test

\begin{tabular}{|c|c|c|c|c|}
\hline \multirow{3}{*}{ Laboratory number } & \multicolumn{4}{|c|}{ Analyte } \\
\hline & \multicolumn{2}{|c|}{ Lead (Assigned value $=34.2 \mu \mathrm{g} / \mathrm{kg}$ ) } & \multicolumn{2}{|c|}{ Cadmium (Assigned value $=126 \mu \mathrm{g} / \mathrm{kg}$ ) } \\
\hline & Analytical result $(\mu \mathrm{g} / \mathrm{kg})$ & Z-score & Analytical result $(\mu \mathrm{g} / \mathrm{kg})$ & Z-score \\
\hline $17^{*}$ & 29.2 & -0.7 & 97.6 & -1.0 \\
\hline
\end{tabular}

${ }^{*}$ Animal, Plant and Fisheries Quarantine and Inspection Agency.

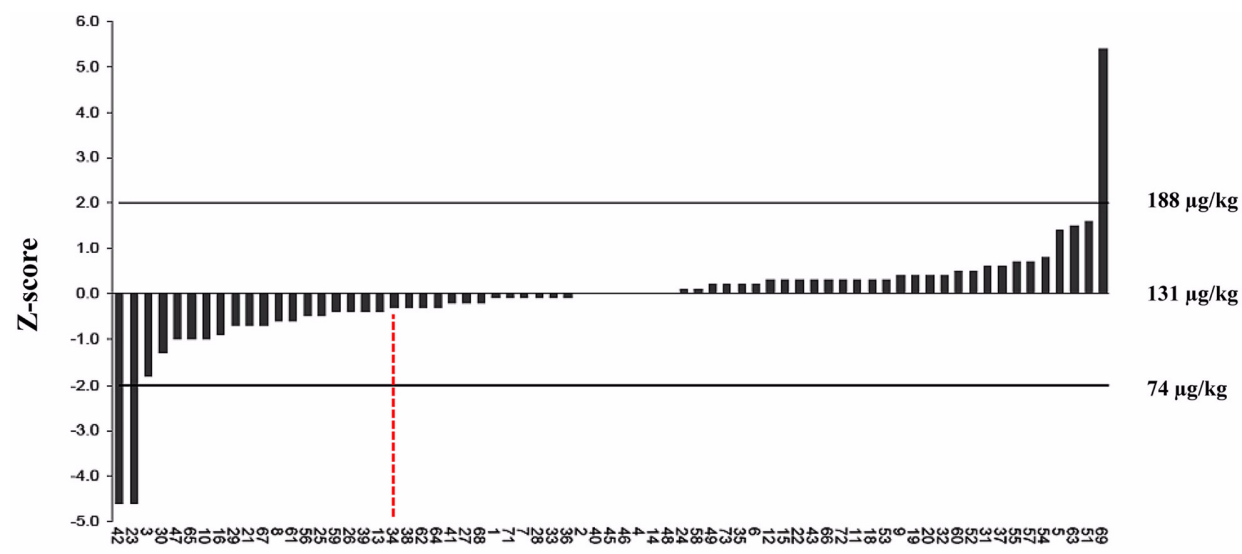

\section{Laboratory Number}

Fig. 2. Result of FAPAS ${ }^{\circledR}$ proficiency test for cadmium in milk powder. The number of our laboratory is 34. C Crown copyright 2010 Fera. Reproduced with the permission of the Controller of Her Majesty's Stationery Office. Any interpretation of these figures is the responsibility of the author and is not endorsed by FAPAS ${ }^{\circledR}$.

를 표준편차로 나눈 값인 z-score로 평가한다. Z-score의 절대값이 2 보다 적은 경우에 분석 숙련도가 충분한 것 으로 인정할 수 있다. 2010년 5 6월에 실시된 $\mathrm{FAPAS}^{\circledR}$ Proficiency Test 보고서(Metallic Contaminants in Milk Powder Report 07138, May-June 2010, The Food and Environment Research Agency, UK)에 실린 우유분말에 서의 카드뮴 분석결과를 Table 3에 나타내었다. 37개 국 가에서 82 개 실험실이 참여하였으며, 이 중 69개 실험 실에서 제출한 측정값이 신뢰성이 있는 것으로 확인 되 었다. 우유분말에 들어있는 실제 카드뮴 농도는 $131 \mu \mathrm{g} /$ $\mathrm{kg}$ 이며 측정값은 $121 \mu \mathrm{g} / \mathrm{kg}$ 으로 $\mathrm{z}$-score가 -0.3 이었으므 로 시험법 및 숙련도의 신뢰성이 확인되었다. 본 시험에
참여한 69개 실험실의 측정값과 z-score는 Fig. 2와 같다. 또한 2010년 8 10월에 실시된 FAPAS ${ }^{\circledR}$ Proficiency Test 보고서(Metallic Contaminants in Cocoa Powder Report 07143, August-October 2010, The Food and Environment Research Agency, UK)에 실린 코코아분말 에서의 납과 카드뮴의 분석결과는 Table 4 에 나타내었 다. 28 개 국가에서 53 개 실험실이 참여하였으며, 이 중 47개 실험실에서 제출한 측정값이 신뢰성이 있는 것으 로 확인되었다. 코코아분말에 들어있는 실제 납의 농도 는 $34.2 \mu \mathrm{g} / \mathrm{kg}$ 이고 측정값이 $29.2 \mu \mathrm{g} / \mathrm{kg}$ 으로 $\mathrm{z}$-score는 -0.7 이었다. 실제 카드뭄의 농도는 $126 \mu \mathrm{g} / \mathrm{kg}$ 이며 측정 값은 $97.6 \mu \mathrm{g} / \mathrm{kg}$ 으로 $\mathrm{z}$-score가 -1.0 이었다. 이로써 납과 


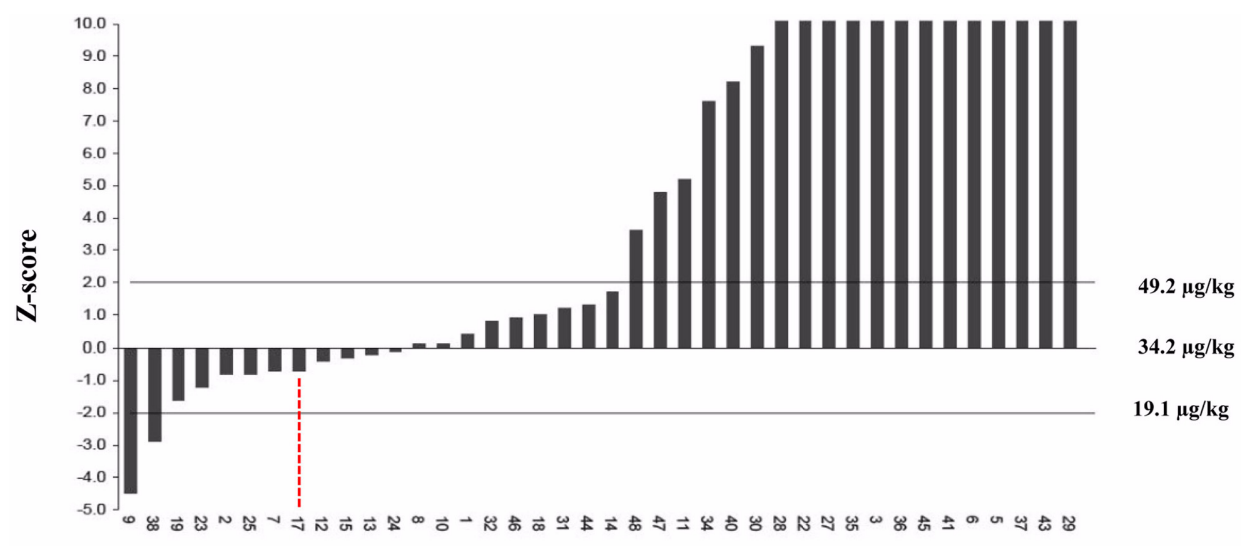

Laboratory Number

Fig. 3. Result of FAPAS ${ }^{\circledR}$ proficiency test for lead in cocoa powder. The number of our laboratory is 17. C Crown copyright 2010 Fera. Reproduced with the permission of the Controller of Her Majesty's Stationery Office. Any interpretation of these figures is the responsibility of the author and is not endorsed by FAPAS ${ }^{\mathbb{R}}$.

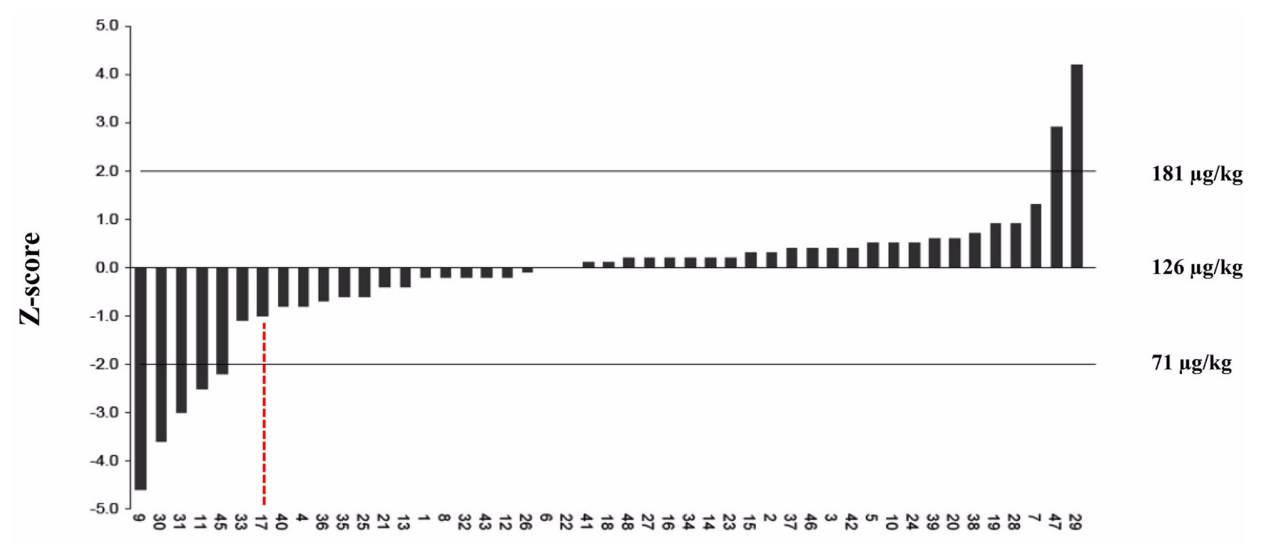

\section{Laboratory Number}

Fig. 4. Result of FAPAS ${ }^{\circledR}$ proficiency test for cadmium in cocoa powder. The number of our laboratory is 17. C) Crown copyright 2010 Fera. Reproduced with the permission of the Controller of Her Majesty's Stationery Office. Any interpretation of these figures is the responsibility of the author and is not endorsed by FAPAS ${ }^{\mathbb{R}}$.

카드뮴의 시험법 및 분석 숙련도의 신뢰성이 인정되었 다. 본 시험에 참여한 실험실의 측정치와 z-score 분포도 를 Fig. 3과 4에 나타내었으며, 카드뮴에 비해 납의 측 정결과가 $\mathrm{z}=|2|$ 를 벗어나는 정도와 빈도가 큰 것을 알 수 있었다.

\section{고 찰}

시료 분해에 사용한 질산의 순도가 분석결과에 영향
을 미치는 것으로 확인 된 후 시료 분해용 질산은 ultra grade를 사용하였다. CRM을 이용한 질산 등급의 비교 시험 결과에서 얻은 카드뮴과 납의 회수율 및 표준편차 가 모두 양호한 것으로 확인되었으므로 분석방법의 정 확도와 정밀도는 신뢰할 수 있었다. 국제적으로 수행된 비교숙련도시험 결과, 축산물에서의 납과 카드뮴의 zscore 절대값이 모두 2 이하로 확인됨에 따라 사용된 시 험법의 신뢰성을 다시 한 번 확인할 수 있었다. 측정값 과 실제 중금속 농도와의 차이는 바탕시험용액(system 
blank)과 매질의 차이에 원인이 있는 것으로 추정되었 다. 시료와 바탕시험용액을 동일 조건에서 분해하고 기 기분석하기 때문에 오직 시료만이 물리적 간섭을 받을 가능성이 있다. 그러므로 바탕시험용액의 분석값이 시 료 분석값에 비하여 상대적으로 높을 수 있고 이로 인 해 실제 보다 큰 값이 바탕시험용액의 보정 과정에서 감 해질 수 있다 [2]. 또 다른 원인으로는 매질에 존재하는 방해물질의 간섭을 생각 할 수 있다. 본 연구에서 사용 된 전처리 과정은 축산물 시료에 적당하도록 확립하였 기에 매질이 다른 시료에서의 중금속 분석에는 적절하 지 않을 수 있다. 실제 우유분말과 코코아분말에서의 분 석결과를 살펴보면, 코코아분말에서 z-score가 더 많이 벗어나는 것을 확인 할 수 있었다. 분석기기의 편류도 항상 나타나는 현상임으로 측정값의 오차에 대한 허용 범위를 설정하거나, 분석과정의 각 단계별 측정불확도 를 계산하여 결과값과 함께 표기하는 방법도 권장되고 있다 [2].

$\mathrm{CRM}$ 을 이용한 회수율 분석결과에서 납과 카드뮴의 원소별 분석 경향을 파악해 본 결과, 카드뭄에 비하여 납 분석 결과의 정밀도가 낮은 것으로 확인되었다. 특히 supra grade의 질산을 사용하여 납을 분석한 경우, 결과 값에 대한 표준편차가 높게 나타났다. 이러한 결과는 카 드뮴에 비하여 납의 경우, 시약, 시험 기구 및 실험실 환 경 등의 바탕오염(background contamination)이 큰 영향 으로 작용함을 짐작할 수 있다. 납 분석 방법이 계속 발 전하고 있으나 여전히 오차가 크게 발생함을 몇몇 연구 자가 보고하여왔다 $[4,7]$. 실제로 질산, 과산화수소 및 초 순수 정제수를 기기분석 하였을 때 납의 오염도는 카 드뮴에 비하여 크게 나타났었다. 또한 전처리과정 중 분 해용기의 오염도를 고려하지 않았을 경우 납의 정확도 가 크게 낮아지는 것을 확인한 바 있었다. 그러므로 유 해중금속 분석 시에는 원소별 바탕오염을 파악하고 이 를 개선하여야 한다. 중금속은 환경유래의 유해물질이 므로 실험과정 중 오염을 완전히 차단하기가 매우 어렵 기 때문에 지속적인 실험실의 오염원 점검을 통한 시험 법개선이 필요하다. 보다 정확한 분석 결과를 얻기 위하 여 바탕시험용액이 과대 보정될 수 있는 점을 참작하고 시료의 매질별, 중금속의 원소별로 최적의 분석이 이루 어지도록 매 시험에 신뢰성 확보가 필요한 것으로 사료 되는 바이다.

\section{참고문헌}

1. D'Ilio S, Petrucci F, D'Amato M, Di Gregorio M, Senofonte $\mathbf{O}$, Violante $\mathbf{N}$. Method validation for determination of cadmium and lead in offal by means of quadrupole inductively coupled plasma mass spectrometry. J Agric Food Chem 2008, 56, 1158411588 .

2. Jorhem L, Engman J. Determination of lead, cadmium, zinc, copper, and iron in foods by atomic absorption spectrometry after microwave digestion: NMKL collaborative study. J AOAC Int 2000, 83, 1189-1203.

3. Jorhem L, Sundström B, Engman J, Astrand-Yates C, Olsson I. Levels of certain trace elements in beef and pork imported to Sweden. Food Addit Contam 1996, 13, 737-745.

4. Key PE, Patey Al, Rowling S, Wilbourn A, Worner FM. International proficiency testing of analytical laboratories for foods and feeds from 1990 to 1996: the experiences of the United Kingdom Food Analysis Performance Assessment scheme. J AOAC Int 1997, 80, 895-899.

5. Lee MH, Lee HS, Son SW, Jung GS, Park JM, Kim SK. A study on sample preparation for the analysis of trace elements in foods of animal origin by ultra high pressure microwave digestion. Korean J Vet Res 2003, 43, 393-398.

6. López-Alonso M, Miranda M, Castillo C, Hernández J, García-Vaquero M, Benedito JL. Toxic and essential metals in liver, kidney and muscle of pigs at slaughter in Galicia, north-west Spain. Food Addit Contam 2007, 24, 943-954.

7. López Alonso M, Prieto Montaña FP, Miranda M, Castillo C, Hernández J, Luis Benedito J. Interactions between toxic ( $\mathrm{As}, \mathrm{Cd}, \mathrm{Hg}$ and $\mathrm{Pb}$ ) and nutritional essential (Ca, Co, Cr, Cu, Fe, Mn, Mo, Ni, Se, Zn) elements in the tissues of cattle from NW Spain. Biometals 2004, 17, 389-397.

8. Muñoz O, Bastias JM, Araya M, Morales A, Orellana C, Rebolledo R, Velez D. Estimation of the dietary intake of cadmium, lead, mercury, and arsenic by the population of Santiago (Chile) using a Total Diet Study. Food Chem Toxicol 2002, 43, 1647-1655.

9. Rudy M. The analysis of correlations between the age and the level of bioaccumulation of heavy metals in tissues and the chemical composition of sheep meat from the region in SE Poland. Food Chem Toxicol 2009, 47, 1117-1122. 